\title{
AN INTICETUS-LIKE (CETACEA, ODONTOCETI) CHEEK TOOTH FROM THE PIETRA LECCESE (MIOCENE, SOUTHERN ITALY)
}

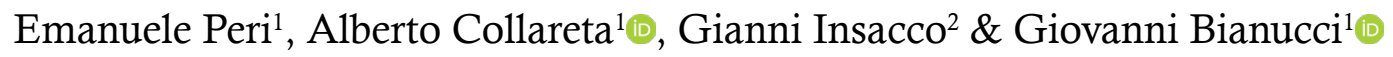 \\ ${ }^{1}$ Dipartimento di Scienze della Terra, Università di Pisa, via Santa Maria 53, 56126 Pisa (Italy); manuilrosso@alice.it; alberto.collare- \\ ta@unipi.it; giovanni.bianucci@unipi.it. \\ ${ }^{2}$ Museo Civico di Storia Naturale di Comiso, Comiso, 97013, Ragusa (Italy); g.insacco@comune.comiso.rg.it
}

KEYWORDS:
Inticetidae;
Mediterranean sea; palaeo-
biogeography;
Pietra leccese;
toothed whales.

KEYWORDS:

Inticetidae; biogeography;

toothed whales.

\section{Bullet-Points Abstract}

- We report the find of an Inticetus-like cheek tooth from the Miocene of southern Italy.

- We identify this specimen as belonging to cf. Inticetus sp.

- This finding brings evidence of faunal exchanges between the Mediterranean Sea and the Pacific Ocean.

- This faunal exchange likely happened via the Central America Seaway.

\section{INTRODUCTION}

Teeth in mammals are often important for the systematic study of the fossil components of this class, like the order Rodentia, for which teeth are highly diagnostic and many fossil species are known only by their dental remains. However, teeth have not the same taxonomic value in all groups of mammals: for cetaceans, teeth often cannot define a particular species, although some odontological features contribute to identify certain families. Here we report the find of an isolated cetacean tooth collected near the village of Melpignano (Lecce Province, southeastern Italy) from the "Pietra leccese" formation. Pietra leccese is a Miocene (upper Burdigalian to lower Messinian) calcarenite that is renowned worldwide for its abundant content of fossil marine vertebrates, which includes turtles, bony and cartilaginous fishes, and particularly cetaceans (both odontocetes and mysticetes). Cetacean remains include the holotypes of Archaeschrichtius ruggeroi Bisconti \& Varola, 2006 (Mysticeti, Eschrichtiidae), Messapicetus longirostris Bianucci et al., 1992 (Odontoceti, Ziphiidae), Rudicetus squalodontoides (Capellini, 1878) (Odontoceti, Kentriodontidae), and Zygophyseter varolai Bianucci \& Landini, 2006 (Odontoceti, Physeteroidea), as well as several odontocete remains belonging to Squalodontidae and Eurinodelphinidae (Bianucci \& Varola, 2014).

\section{Materials ANd Methods}

The cetacean dental specimen here described is stored at the Museo Civico di Storia Naturale of Comiso with catalogue number MCSNC 4457 (Insacco, 2014). It exhibits a roughly half-circular and laterally com- pressed crown with an almost smooth enamel surface. This tooth bears several large accessory denticles: along the anterior side there are four denticles, whereas six denticles take place on the posterior side. The denticles are radially positioned and slightly bowed toward the main cusp, forming an arc. Their size gradually decreases moving to the base of the crown; moreover, in this region, there are weak subvertical grooves on the enamel. Although most of the root is missing, we thought that the tooth was originally double rooted because of the presence of a slight incision under the base of the crown. Considering the Miocene age of MCSNC 4457, we hypothesize that it represents a cheek tooth belonging to a basal member of the clade Neoceti (i.e. Mysticeti + Odontoceti).

In order to identify the bearer of this tooth, we compared MCSNC 4457 to several groups of early branching fossil neocetes. The selection of the taxa used in this study was mainly based on morphological similarities with the Melpignano specimen. Among basal mysticetes, Coronodon havensteini Geisler et al., 2017, a fossil whale recently discovered from the Oligocene of the South Carolina (Ashley Formation), shows important morphological affinities with MSNC 4457, including the presence of several broad-based accessory denticles that form an arc and smooth surface of the enamel. We also compared MCSNC 4457 with Squalodontidae, a family of basal odontocetes characterized by having laterally compressed postcanine teeth with several accessory denticles (Dal Piaz, 1916; Rothausen, 1958; 1961; 1967; 1968). Finally, we compared the tooth from Melpignano with Inticetus vertizi Lambert et al., 2018, a highly autapomorphic heterodont toothed whale from the early Miocene of Peru

Corresponding author email: manuilrosso@alice.it

How to cite: Peri et al. (2018). An Inticetus-like (Cetacea, Odontoceti) cheek tooth from the Pietra Leccese (Miocene, Southern Italy). Fossilia, Volume 2018: 33-35. https://doi.org/10.32774/FosRepPal.20.1810.113335 
(Chilcatay Formation). This species, that form the monospecific family Inticetidae, bears laterally flattened cheek teeth with multiple large and bowed denticles, that give a half-circular shape to the postcanine teeth.

\section{Results AND Discussions}

The only known mysticete with a cheek tooth morphology similar to MCSNC 4457 is Coronodon havensteini (Geisler et al., 2017). However, accessory denticles in $C$. havensteini are erect while those of MCSNC 4457 are weakly bowed. Furthermore, $C$. havensteini has been dated to the lower Oligocene (Rupelian) (Geisler et al., 2017) whereas the Pietra leccese lower portions are late Burdigalian in age. Hence, MCSNC 4457 is likely too young to be considered a cheek tooth of $C$. havensteini. Therefore, our morphological observations, coupled with the chronostratigraphic considerations, prevent any tentative attribution of MSNC 4457 to $C$. havensteini or other Coronodon-like toothed mysticetes. Alternatively, we hypothesised that MCSNC 4457 could belong to a member of the basal odontocetes family Squalodontidae (e.g. Squalodon Grateloup, 1840 and Eosqualodon Rothausen, 1968). However, squalodontids generally have more vertical and less pronounced denticles than our specimen, in addition to strong ornamentation of the enamel and a more triangular and pointed shape of the cheek teeth. The squalodontid-like Neosqualodon Dal Piaz, 1904 exhibits more evident accessory denticles, but these are less numerous (normally numbering three on the distal side and two on the mesial side) and less bowed than MCSNC 4457. Moreover, the teeth of Neosqualodon are much smaller than MCSNC 4457. Consequently, the morphological distance precludes the belonging of the tooth from the Pietra leccese to any member of Squalodontidae. The greatest similarities can be found with the cheek teeth of Inticetus vertizi from Peru. Indeed, MCSNC 4457 shares with the double-rooted cheek teeth of Inticetus a laterally compressed and half-circular crown, with several large and bowed denticles, and reduced ornamentation. Furthermore, in both the holotype of I.vertizi and the specimen from Pietra leccese, slight subvertical grooves are present on the enamel. The only morphological difference between MCSNC 4457 and the cheek teeth of $I$. vertizi is the smaller number of denticles in the postcanine teeth of the latter (Lambert et al., 2018). I. vertizi is dated to the early Miocene (Burdigalian) (Lambert et al., 2017), a time span that is compatible with the stratigraphic range of Pietra leccese. Therefore, based on morphological and chronostratigraphic considerations, we identified MCSNC 4457 as belonging to cf. Inticetus sp.

\section{Concluding Remarks}

From a palaeobiogeographical point of view, the presence of forms close to Inticetus Lambert et al., 2018 in both the southeastern Pacific Ocean and the Medi- terranean Sea could be due to a faunistic interchange between the Indo-Pacific Ocean and the Mediterranean Sea through the Tethyan Seaway, the latter passage being still active in early Miocene times (Reuter et al., 2009). More probably, inticetids dispersed via the Central America Seaway: indeed, the Panama Isthmus did not exist until latest Miocene times (Jacobs et al., 2004), so it is plausible that inticetids dispersed through the Atlantic Ocean, thus recalling what has been proposed by Bianucci et al. (2016) for the beaked whale genus Messapicetus in late Miocene times.

In conclusion, the find of MCSNC4457 provides new hints about the biogeographical relationships between the Pacific and the Atlantic-Mediterranean realms in Miocene times and suggests that our knowledge on the distribution patterns of the Inticetus-like heterodont odontocetes is still fragmentary.

\section{ACKNOWLEDGEMENTS}

Thanks to Mariano Serafini for his fundamental contribution in donating to the Museo Civico di Storia Naturale of Comiso the cetacean tooth MCSNC 4457. We are also grateful to Raymond L. Bernor and an anonymous reviewer for their useful suggestions and constructive criticisms.

\section{REFERENCES}

Bianucci G. \& Landini W. (2006). Killer sperm whale: a new basal physeteroid (Mammalia, Cetacea) from the Late Miocene of Italy. Zoological Journal of the Linnean Society, 148 (1): 103-131.

Bianucci G. \& Varola A. (2014). I cetacei fossili della Pietra leccese nei musei del Salento. Museologia Scientifica Memorie, 13: 130-134.

Bianucci G., Collareta A., Post K., Varola A. \& Lambert O. (2016). A new record of Messapicetus from the Pietra leccese (late Miocene, southern Italy): antitropical distribution in a fossil beaked whale (Cetacea, Ziphiidae). Rivista Italiana di Paleontologia e Stratigrafia, 122 (1): 6374.

Bianucci G., Landini W. \& Varola A. (1992). Messapicetus longirostris, a new genus and species of Ziphiidae (Cetacea) from the Late Miocene of "Pietra leccese" (Apulia, Italy). Bollettino della Società Paleontologica Italiana, 31 (2): 261-264

Bisconti M. \& Varola A. (2006). The oldest eschrichtiid mysticete and a new morphological diagnosis of Eschrichtiidae (gray whales). Rivista Italiana di Paleontologia e Stratigrafia, 112 (3): 447-457.

Capellini G. (1878). Della Pietra Leccese e di alcuni suoi fossili. Memorie della Reale Accademia di Scienze dell'Istituto di Bologna, 9 (3): 227-258.

Dal Piaz G. (1904). Neosqualodon nuovo genere della famiglia degli squalodontidi. Mémoires de la Société Paléontologique Suisse, 31:1-19.

Dal Piaz G. (1916). Gli odontoceti del Miocene del Bellunese. Memorie dell'Istituto Geologico della Regia Università di Padova, 4: 1-94.

Geisler J. H., Boessenecker R.W., Brown M. \& Beatty B.L. (2017). The Origin of Filter Feeding in Whales. Current Biology, 27 (13): 2036-2042.

Grateloup J. P. S. (1840). Description d'un fragment de ma- 
choire fossile, d'un genre nouveau de reptile (saurien). Actes de l'Académie Nationale des Sciences Belles-Lettres et Arts de Bordeaux, 2:201-210.

Insacco G. (2014). I Cetacei fossili del Museo Civico di Storia Naturale di Comiso (Ragusa). Museologia Scientifica Memorie, 13: 130-134.

Jacobs D. K., Haney T. A. \& Louie K. D. (2004). Genes, diversity, and geological process on the Pacific coast. $A n$ nual Review of Earth and Planetary Sciences, 32: 601-652.

Lambert O., de Muizon C., Malinverno E., Di Celma C., Urbina M. \& Bianucci G. (2018). A new odontocete (toothed cetacean) from the Early Miocene of Peru expands the morphological disparity of extinct heterodont dolphins. Journal of Systematic Palaeontology, 16 (12): 981-1016.

Reuter M., Piller W. E., Harzhauser M., Mandic O., Berning B., Rögl F., Kroh A., Aubry M.-P., Wielandt-Schuster U. \& Hamedani A. (1999). The Oligo-/Miocene Qom Formation (Iran): evidence for an early Burdigalian restriction of the Tethyan Seaway and closure of its Iranian gateways. International Journal of Earth Sciences (Geol Rundsch), 98 (3): 627-650.

Rothausen K. (1958). Marine Vertebraten (Odontaspidae, Lamnidae, Sparidae, Dermochelyidae, Squalodontidae) im oberoligozänen Meeressand von Süchteln und Düsseldorf. Fortschritte in der Geologie von Rheinland und Westfalen, 1: 363-384.

Rothausen K. (1961). Über Microcetus, einen kleinen Squalodontiden aus dem Oberoligozän. Neues Jahrbuch für Geologie und Paläontologie, 112 (1): 106-118.

Rothausen K. (1967). Die Klimabindung der Squalodontoidea (Odontoceti, Mamm.) und anderer mariner Vertebrata. Sonderveröffentlichung des Geologischen Institut der Universität zu Köln, 13: 157-166.

Rothausen K. (1968). Die Systematische Stellung der Europäischen Squalodontidae (Odontoceti, Mamm.). Paläontologische Zeitschrift, 42 (1-2): 83-104.

Manuscript received 13 July 2018

Received after revision 1 October 2018

Accepted 3 October 2018 